\title{
FAKTISKĀS RĪCIIBAS KLASIFIKĀCIJA JEB FAKTISKĀS RĪCĪBAS VEIDI
}

\section{TYPES OF REAL ACTION}

\author{
Anita Koval̦evska, Mg. iur. \\ Latvijas Universitātes Juridiskās fakultātes \\ Valststiesību zinātṇu katedras lektore
}

\begin{abstract}
Summary
The classification of real actions has two purposes: 1) to describe the diversity of real actions; 2) to determine the legal norms applicable in a specific situation. The paper examines what types of real action classifications can be used to achieve these goals. To characterize the diversity of real actions, it can be divided into the following types: 1) action and inaction; 2) favorable and unfavorable real action; 3) lawful and unlawful real action, etc. In order to determine the legal norms applicable in a specific situation, it is important to divide real actions into the following types: 1) planned and unplanned real action; 2) intentional and unintentional real action; 3 ) one-off and long-term real action, etc.
\end{abstract}

Atslēgvārdi: faktiskā rīcība, klasifikācija, darbība un bezdarbība, plānota un neplānota faktiskā rīcība.

Keywords: real action, calssification, action and inaction, planned and unplanned real action.

\section{Ievads}

Par galveno administratīvā procesa instrumentu uzskata administratīvo aktu. Taču vēl viens administratīvā procesa pamatinstruments ir faktiskā rīcība, kas Administratīvā procesa likumā ir regulēta daudz mazākā apjomā nekā administratīvais akts. ${ }^{1}$

Latvijas Universitātes Juridiskajā fakultātē docētajā studiju kursā "Administratīvā procesa tiesības" atsevišks temats ir veltīts administratīvā akta klasifikācijai. Arī tiesību zinātnē šim tematam tiek pievērsta uzmanība. ${ }^{2}$ Savukārt faktiskajai rīcībai līdz šim ir pievērsta daudz mazāka uzmanība. Taču arī faktiskās rīcības gadījumā tas ir nozīmīgs jautājums. Tāpat kā citu tiesību institūtu gadījumā, arī faktiskās rīcības gadỉjumā tās klasifikācija var kalpot vismaz diviem mērḳiem. Pirmkārt, faktiskās rīcỉbas klasifikācija var palīdzēt raksturot faktiskās rīcības daudzveidību, tādējādi palīdzot arī izprast faktiskās rīcības jēdzienu. Otrkārt,

\footnotetext{
${ }^{1}$ Višķere I. Publisko tiesību līgumi un to kontrole administratīva procesa kārtībā. Jurista Vārds, 03.02.2009., Nr. 5.

2 Paine F. J. Vācijas vispārīgās administratīvās tiesības. Vācijas Administratīiā procesa likums, 4. izd. Rīga: Tiesu namu aǵentūra, 2002, 130.-146. lpp.
} 
faktiskās rīcības klasifikācija var palīdzēt noteikt konkrētā situācijā piemērojamās tiesību normas, jo Administratīvā procesa likumā̄ ir ietverts arī tāds tiesiskais regulējums, kas piemērojams tikai konkrēta veida faktiskās rīcības gadījumā.

\section{Faktiskās rīcības klasifikācijas veidi, kas raksturo faktiskās rīcỉbas daudzveidibu}

Ja faktisko rīcību klasificē, lai raksturotu tās daudzveidību, tad ir iespējams izdomāt lielu skaitu dažādu klasifikācijas veidu. Referātā tiks apskatīit klasifikācijas veidi, kas ir balstīiti uz faktiskās rīcības pazīmēm, un klasifikācijas veidi, kas ir balstīti uz administratīvā akta klasifikāciju.

Balstoties uz faktiskās rīcības pazīmēm, autore piedāvā šādus faktiskās rīcības klasifikācijas veidus:

1) pēc faktiskās rīcības formas - darbība vai bezdarbība;

2) pēc skarto personu veida: a) attiecībā uz juridisku personu veikta faktiskā rīcība un attiecībā uz fizisku personu veikta faktiskā rīcỉba, un b) attiecībā uZ amatpersonu vai iestādei îpaši pakḷautu personu veikta faktiskā rīcība, un faktiskā rīcība, kas veikta attiecībā uz personu, kas nav amatpersona un nav iestādei īpaši pakḷauta persona;

3) pèc faktiskā rīcības veicēja: faktiskā rīcība, ko veic iestāde institucionālā nozīmē, iestādes struktūrvienība, iestādes amatpersona, privātpersona, kam delegèta publiska uzdevumu pildīšana;

4) pēc faktisko seku veida: rīcỉba, uz kuru privātpersonai ir tiesības, un rīcība, kuras rezultātā ir radies vai var rasties personas subjektīvo tiesību vai tiesisko interešu aizskārums.

Faktiskās rīcības iedalījums darbībā vai bezdarbībā ${ }^{4}$ ir tieši minēts faktiskās rīcības legāldefinīcijā Administratīvā procesa likuma 89. pantā un ir saistîts ar pazīmi "uz āru vērsta rīcība", skaidrojot rīcības formas. Faktiskās rīcības iedalījums tādā, kas ir veikta attiecībā uz juridisku personu, un tādā, kas ir veikta attiecībā uz fizisku personu, ir saistīts ar faktiskās rīcibas pazīmi "veikta attiecībā uz individuāli noteiktu personu vai personām". Savukārt iedalījums pēc faktiskās rīcības veicēja ir saistīts ar pazīmi "veic iestāde". Autores ieskatā, šie klasifikācijas veidi ir pašsaprotami un papildu komentārus neprasa.

Nozīmīgāki ir pārējie divi klasifikācijas veidi. Faktiskās rīcības iedalījums tādā faktiskā rícībā, kas ir veikta attiecībā uz amatpersonu vai iestādei ipašsi pakḷautu personu ${ }^{5}$, un tādā, kas veikta attiecībā uz personu, kas nav amatpersona vai iestādei īpaši pakḷauta persona, ir saistīts ar pazīmi "uz āru vērsta rīcỉba". Lai par faktisko rīcību atzītu tādu rīcību, kas veikta attiecībā uz amatpersonu vai ìpaši pakḷautu personu, šai rìcībai ir būtiski jāskar šo personu cilvēktiesības. ${ }^{6}$ Ja būs skartas kādas citas tiesības, kas nav cilvēktiesības, tā būs iestādes iekšējā rīcība, nevis faktiskā rīcība.

\footnotetext{
3 Administratīvā procesa likums: LV likums. Latvijas Vēstnesis, 14.11.2001., Nr. 164.

${ }^{4}$ Par bezdarbību kā faktisko rīcību sīkāk sk.: Briede J. Iestādes bezdarbība kā faktiskās rīcības forma. Grām.: Tiesību efektivitāte postmodernā sabiedrībā: Latvijas Universitātes 73. zinātniskās konferences rakstu krājums. Rīga: LU Akadēmiskais apgāds, 2015, 289.-297. lpp.

5 Jēdzienus “amatpersona” un "iestādei īpaši pakḷauta persona” sk.: Briede J., Danovskis E., Koval̦evska A. Administratīvās tiesības. Mācību grāmata. 2. izd. Rīga: Tiesu namu aǵentūra, 2021, 98. lpp.

6 Augstākās tiesas 29.08.2006. lēmums lietā Nr. SKA-498/2006. Pieejams: http://www.at.gov.lv/lv/tiesuprakse/judikaturas-nolemumu-arhivs/administrativo-lietu-departaments/hronologiska-seciba.
} 
No Administratīvā procesa likuma 89. panta izriet, ka faktiskās sekas var rasties divos gadījumos: 1) ja privātpersonai uz šo rīcību ir tiesības un 2) ja šis rīcības rezultātā ir radies vai var rasties personas subjektīvo tiesību vai tiesisko interešu aizskārums. Pirmajā gadījumā faktiskā rīcība var būt gan darbības, gan bezdarbības formā. Piemēram, atbildes sniegšana uz privātpersonas iesniegumu Iesniegumu likuma kārtībā ir faktiskā rīcỉba darbības formā, savukārt atbildes nesniegšana uz privātpersonas iesniegumu Iesniegumu likuma kārtỉbā ir faktiskā rīcība bezdarbības formā. Tāpat ieslodzītā aizvešana pie ārsta akūtu zobu sāpju gadījumā ir faktiskā rīcība darbības formā, savukārt ieslodzītā neaizvešana pie ārsta akūtu zobu sāpju gadījumā ir faktiskā rīcība bezdarbības formā. Otrajā gadījumā faktiskā rīcība ir tikai darbības formā. Piemēram, ieslodzijuma vietu administrācija prettiesiski izṇem no sūtījuma, ko ieslodzītajam sūtījis draugs, sienas kalendāru.

Pievēršoties tam, kuri no administratīvo aktu klasifikācijas veidiem būtu izmantojami arī faktiskās rīcības klasificēšanā, autore secina, ka atsevišķu klasifikācijas veidu nepiemērojamību faktiskajai rīcībai rada tieši tas, ka konkrētais klasifikācijas veids administratìvos aktus klasificē pēc to radīto tiesisku seku veida vai ir lielā mērā balstīts uz tiesiskajām sekām. Piemēram, administratīvos aktus iedala tiesiskās attiecības nodibinošos, tiesiskās attiecības grozošos, tiesiskās attiecības izbeidzošos, tiesisko vai faktisko situāciju konstatējošos administratīvajos aktos un atteikumos. Šis iedalījums faktiskajai rīcībai nav piemērojams. Tā vietā var izmantot faktiskās rīcības klasifikāciju pēc faktisko seku veida. Autores ieskatā, nav izmantojama arī administratīvo klasifikācija pēc to spēkā esības (vēl spēkā nestājies, spēkā esošs, spēkā neesošs, spēku zaudējis), jo faktiski šis iedalījums ir balstīts uz to, vai administratīvais akts konkrētā brīdī jau/vēl rada tiesiskas sekas. Ar šo klasifikācijas veidu zināmā mērā varētu salīdzināt plānotas faktiskās rīcības iedalỉjumu plānotā7, bet vēl neuzsāktā faktiskā rīcībā; plānotā, uzsāktā, bet vēl nepabeigtā faktiskā rīcībā un plānotā un jau pabeigtā faktiskā rīcībā, jo šāds iedalījums būtu balstīts uz to, vai faktiskā rīcība jau/vēl rada faktiskas sekas.

Autore uzskata, ka faktiskajai rīcībai viegli var piemērot administratīvo aktu iedalījumu: 1) labvēlīgos, nelabvēlīgos, daḷeji labvēlīgos administratīvos aktos un administrativos aktos ar dubultu ietekmi; 2) tiesiskos un prettiesiskos administratīvos aktos; 3) apstrīdamos un neapstrīdamos administratīvos aktos (pārsūdzamos un nepārsūdzamos administratīvos aktos), 4) obligātos, izdošanas izvēles, satura izvēles un brīvos administratīvos aktos.

Arī faktiskā rīcība var būt privātpersonas interesēm atbilstoša (labvēlīga) un privātpersonas interesēm neatbilstoša (nelabvēlīga), kā, piemēram, jau minētā atbildēšana uz privātpersonas iesniegumu un neatbildēšana. Interesants ir jautājums, vai faktiskā rīcība var būt daḷeji labvēlīga. Pēc autores domām, tas ir iespējams, ja faktisko rīcību, kas potenciāli sastāv no vairākām darbībām, uztver kā vienotu faktisko rīcību, nevis kā vairākas atsevišksas faktiskās rīcības. Piemēram, ja persona Informācijas atklātības likuma kārtībā ar vienu pieprasījumu ir pieprasījusi vairākas informācijas vienības, tad iestāde var daḷu no pieprasītās informācijas izsniegt, bet daḷu neizsniegt. Ja to uztver kā vienotu faktisko rīcību, tad to var uzskatīt par daḷēji labvēlīgu (attiecībā uz informācijas vienībām, kas tika izsniegtas) un daḷēji nelabvēlīgu (attiecībā uz informācijas vienībām, kas netika izsniegtas). Tāpat ir iespējama arī faktiskā rīcība ar dubultu ietekmi, piemēram, kad iestāde izsniedz personai pieprasīto informāciju (šai personai labvēlīga faktiskā rīcība), taču izsniegtā

\footnotetext{
7 Par plānotu faktisko rīcību sk. referāta 2. nodaḷu.
} 
informācija satur arī kādas fiziskas personas datus un tie ir izsniegti nepamatoti (datu subjektam nelabvēlīga faktiskā rīcība).

Faktiskā rīcība var būt tiesību normām atbilstoša (tiesiska) un tiesību normām neatbilstoša (prettiesiska) ${ }^{8}$. Tiesiska faktiskā rīcība ir tikai gadījumā, ja tiek veikta darbība, uz kuru ir tiesības. Savukārt, ja netiek veikta darbība, uz kuru ir tiesības (tiek piel̦auta bezdarbỉba), vai tiek veikta darbỉba, ar kuru ir radìts personas tiesību aizskārums, tad tā ir prettiesiska faktiskā rīcība.

Tā kā Administratīvā procesa likuma 91. pants paredz, ka arī faktisko rīcību var apstrīdēt un pārsūdzēt, tad faktiskā rīcība var būt apstrīdama (nav vēl beidzies tās apstrīdēšanas termiņš) vai neapstrīdama (apstrīdēšanas termiņš ir beidzies, un faktiskā rīcība nav apstrīdētā) un pārsūdzama vai nepārsūdzama (atkarībā no pārsūdzības termiṇa iestāšanās vai neiestāšanās) ${ }^{9}$.

Ja faktiskā rīcība pēc tiesisko seku veida ir rīcība, uz kuru personai ir tiesības, tad faktisko rīcību tāpat kā administratīvo aktu var klasificèt pēc rīcības brīvības veida: obligātā faktiskā rīcība, brīvā faktiskā rīcība un daḷeji brīvā faktiskā rīcìba (veikšanas brīvība vai satura brīvība). ${ }^{10}$

Pārējie administratīvo aktu klasifikācijas veidi, pēc autores domām, ir tikai nosacìti (ierobežoti) izmantojami faktiskās rīcības klasifikācijā.

Administratīvos aktus var iedalìt pozitīvos un negatīvos atkarībā no tā, vai tie rada privātpersonai kādas jaunas tiesiskas sekas (gan labvēlīgas, gan nelabvēlīgas) vai nerada. Teorētiski arī faktisko rīcību varētu iedalìt pozitīvā jeb tādā, kas rada jaunas faktiskas sekas, un negatīvā jeb tādā, kas nerada. Taču pozitīva faktiskā rīcība vienmēr būs darbības formā, bet negatìva - bezdarbības formā. Tā kā ir iespējams izmantot Administratīvā procesa likumā tieši minēto faktiskās rīcības iedalījumu darbībā un bezdarbībā, tad faktiskās rīcības klasificēšanai pozitīvā un negatīvā ir tikai ierobežota nozīme, proti, tai ir nozīme tiktāl, ciktāl tas ḷauj vieglāk salīdzināt un piemērot pēc analogiju atziṇas, kas attiecas uz pozitīvu un negatìvu administratīvo aktu. ${ }^{11}$

Administratīvos aktus pēc to formas iedala rakstveidā, mutvārdos, zīmju valodā un ar konkludentām darbībām izdotos administratīvajos aktos. Arī faktiskā rīcība var būt kā rakstveida darbība, piemēram, informācijas sniegšana vai atbildēšana uz iesniegumu, vai mutvārdos veikta darbība, piemēram, prettiesiska personas datu izpaušana mutvārdos. Faktiskā rīcība var būt arī cita veida darbība (ieslodzītā aizvešana pie ārsta, kalendāra izṇemšana no sūtījuma ieslodzìtajam, policijas ierašanās uz izsaukuma vietu), ko nevar raksturot kā zīmju valodā vai ar konkludentām darbībām veiktu, un bezdarbība. Administratīvā akta gadījumā šim iedalïjumam ir nozīme, jo Administratīvā procesa likuma 69. pants regulē to, kad administratīvo aktu var neizdot rakstveidā, bet 67. pants nosaka rakstveidā izdota administratīvā akta sastāvdaļas, turpretim attiecībā uz faktisko rīcību nav tāda tiesiskā regulējuma, kas piešḳirtu nozīmi tam, vai tā ir vai nav veikta rakstveidā.

8 Sal.: Administratīvā procesa likuma 84. pants.

${ }^{9}$ Faktiskās rīcības pārsūdzības termiņš regulēts Administratīvā procesa likuma 188. panta ceturtajā daḷā.

10 Par rīcỉbas brīvību un tās veidiem sk.: Briede J., Danovskis E., Koval̦evska A. 2021, 29.-31. lpp.

11 Piemēram, atziņu, ka negatīvu administratīvo aktu neatcel̦, jo negatīva administratīvā akta izdošanas gadījumā persona parasti tiesā vēršas ar pieteikumu par pozitīva labvēlīga administratīvā akta izdošanu, var pēc analogijas piemērot arī faktiskajai rīcībai, secinot, ka negatīvas faktiskās rīcības jeb bezdarbības gadījumā persona tiesai prasa nevis bezdarbības pārtraukšanu, bet gan pozitīvas faktiskās rīcības jeb labvēlīgas darbības veikšanu. 
Administratīvos aktus var iedalīt izpildāmos un neizpildāmos. Izpildāmi administratīvie akti ir tādi, kuri pēc to izdošanas rada pienākumu vai nu adresātam, vai iestādei veikt uz izpildi vērstas darbības (nojaukt patvaḷigi uzbūvētu būvi, izmaksāt vecuma pensiju, kas piešķirta ar administratīvo aktu). Savukārt neizpildāmi administratīvie akti neprasa veikt nekādas darbības. Neizpildāmi ir konstatējošie administratīvie akti, administratīvie akti, ar kuru personai tiek piešķirts vai atņemts kāds statuss, atteikumi. Šis iedalijjums varētu būt tikai nosacìti attiecināms uz faktisko rīcību, jo faktiskās rīcības gadījumā nevar nošķirt divas stadijas - izdošanu (veikšanu) un izpildi. Izņēmums varētu būt plānota faktiskā rīcība. ${ }^{12}$ Proti, ar izpildāmu administratīvo aktu varētu salīdzināt plānotu faktisko rīcibu, kas vispirms tiek plānota, paziṇota un tikai tad veikta (izpildìta).

Administratīvos aktus iedala arī tādos, kas ir izdoti uz noteiktu terminu, bez termiņa, vai pagaidu administratīvos aktos. Taču šì klasifikācija ne vienmēr ir èrti piemērojama (piemēram, administratīvajam aktam, ar kuru anulē iepriekš izsniegtu ielu tirdzniecỉbas aț̣auju), tāpēc reizēm tā vietā izmanto citu iedalījumu, proti iedalījumu vienreizējos administratīvos aktos (administratīvais akts par ielu tirdzniecỉbas aţ̦aujas anulēšanu) un ilglaicīgos (administratīvais akts par bēgḷa statusa piešķiršanu). Arī faktisko rīcību veiksmīgi var iedalìt vienreizējā (informācijas sniegšana, ieslodzītā aizvešana pie ārsta) un ilgstošā (bezdarbība parasti būs ilgstoša, taču reizēm arī darbība var būt ilgstoša faktiskā rīcība - dzīvojamās kameras sanitārā mezgla videonovērošana ieslodzijuma vietā, ieslodzìtā reliǵiskajai pārliecībai atbilstoša uztura nodrošināšana ieslodzījuma vietā). Savukārt iedalijumu faktiskajā rīcībā, kuru paredzēts veikt noteiktu termiņu, un faktiskajā rīcībā, kuru paredzēts veikt bez noteikta termiṇa (iepriekš minētā videonovērošana var būt paredzēta uz noteiktu termiņu vai nenoteiktu termiņu), ir iespējams attiecināt tikai uz ilgstošu faktisko rīcību darbības formā, kas praksē ir loti reti sastopama. Lìdz ar to šim klasifikācijas veidam faktiskās rīcības gadījumā ir ierobežota nozīme.

\section{Faktiskās rīcības klasifikācijas veidi, kas palīdz noteikt konkrētā situācijā piemērojamās tiesību normas}

Administratīvā procesa likumā ir ļoti mazs tādu normu skaits, kas regulē tieši faktisko rīcību. Administratīvā procesa likuma $B$ daḷā, kas regulē procesu iestādē, faktiskai rīcībai ir veltīti tikai trīs panti - 89., 90. un 91. pants.

No Administratīvā procesa likuma 90. panta pirmās dal̦as kopsakarā ar 65. pantu var secināt, ka juridiski nozīmīga ir faktiskās rīcības klasifikācija pèc rīcỉbas brīvības veida obligātajā faktiskajā rīcībā, brīvajā faktiskajā rìcībā un dalẹji brīvajā faktiskajā rīcībā, jo obligātās faktiskās rīcības gadījumā lietderības apsvērumi iestādei nav jāveic.

Administratĩvā procesa likuma 90. un 91. pantā ir ietverts īpašs regulējums plānotai faktiskai rīcíbai. No 90. panta otrās daļas izriet, ka plānotas faktiskās rīcības gadījumā iestādei pirms tās uzsākšanas ir jāpaziṇo potenciāli skartajai personai (personām) par plānoto faktisko rīcību. Savukārt 91. panta pirmā daḷa paredz, ka plānotas faktiskās rīcíbas gadỉjumā privātpersona var vispirms vērsties iestādē ar iesniegumu par iestādes nodoma mainīšanu, savukārt atbilstoši šā panta otrajai

${ }^{12}$ Par plānotu faktisko rīcību sk. referāta 2. nodaḷu. 
daḷai iestādes lēmumu par šādu iesniegumu var apstrīdēt un pārsūdzēt. Līdz ar to faktiskās rīcības iedalījums plānotā un neplānotā faktiskā rīcībā ir juridiski nozīmīgs, jo iepriekš minētās normas ir piemērojamas tikai plānotas faktiskās rīcības gadījumā.

Plānota ir tāda faktiskā rīcība, kuras veikšana ir iepriekš paredzama un par kuras veikšanu skartajām privātpersonām iepriekš nav zināms. Par plānotu faktisko rīcību iepriekš minēto tiesību normu izpratnē neuzskata faktisko rīcību darbības formā, kas tiek veikta pēc skartās privātpersonas lūguma, proti, pēc privātpersonas lūguma veiktu rīcību, uz kuru personai ir tiesības. ${ }^{13} \mathrm{Lìdz}$ ar to par plānotu faktisko rīcību nav uzskatāma, piemēram, atbildes sniegšana uz iesniegumu Iesniegumu likuma kārtībā. Savukārt pēc iestādes iniciatīvas veikta dzīvojamo kameru videonovērošana ieslodzījuma vietā ir plānota faktiskā rīcība.

Faktiskās rīcības iedalījumu plānotā un neplānotā nevajag jaukt ar faktiskās rīcības iedalījumu apzinātā un neapzinātā faktiskā rīcībā. Administratīiā procesa likuma 89. panta pirmās daḷas otrajā teikumā ir skaidrots, ka par faktisko rīcību atzīstamas arī iestādes darbības, kas neatkarīgi no iestādes nodoma rada tādas faktiskās sekas, kuru rezultātā privātpersonai ir radies vai var rasties būtisks tiesību aizskārums. Šāda faktiskā rīcība ir nepazināta jeb nejauša. No šis normas var arī secināt, ka pretstats neapzinātai faktiskajai rīcībai ir apzināta faktiskā rīcība, kas attiecīgi ir tāda faktiskā rīcība, kad iestāde konkrētās faktiskās sekas rada ar nodomu jeb apzināti (sniedz informāciju, izṇem no sūtījuma ieslodzìtajam kalendāru). ${ }^{14}$ Neapzināta jeb nejauša faktiskā rīcība var būt tikai neplānota, bet apzināta faktiskā rīcība var būt gan neplānota (informācijas sniegšana, kalendāra izņemšana), gan plānota (dzīvojamo kameru videonovērošana ieslodzijjuma vietā pèc iestādes iniciatīvas).

Faktiskās rīcības iedalījums plānotā un neplānotā ir nozīmīgs, arī nosakot pieteikuma priekšmetus procesā tiesā un sprieduma veidu. No Administratīvā procesa likuma 255. panta izriet, ka faktiskās rīcības gadījumā viens no sprieduma veidiem un attiecīgi arī pieteikuma priekšmetiem ir spriedums un pieteikums par aizliegumu veikt faktisko rīcību. Viens no šāda pieteikuma priekšmeta apakšveidiem ir pieteikums par aizliegumu uzsākt faktisko rīcību. Šāds pieteikums ir iespējams tikai plānotas faktiskās rīcības gadījumā, jo tādu var iesniegt tikai tad, ja personai ir paziņots par plānoto nelabvēlīgo faktisko rīcību vēl pirms tās veikšanas.

No pieteikuma priekšmeta noteikšanas viedokḷa nozīmīgi ir arī vairāki jau iepriekš minēti faktiskās rīcības klasifikācijas veidi. Piemēram, faktiskās rīcības iedalijums vienreizējā un ilgstošā ir nozīmīgs, lai noteiktu, kad ir iespējams otrs pieteikuma par aizliegumu veikt faktisko rīcību apakšveids, proti, pieteikums par aizliegumu turpināt faktisko rīcību jeb pieteikums par faktiskās rīcības pārtraukšanu. Šāds pieteikuma priekšmets ir iespējams tikai ilgstošas faktiskās rīcības gadījumā, piemēram, kad cietuma administrācija noteiktā laika posmā veic dzìvojamo kameru videonovērošanu. Šajā kontekstā nozīmīgs arī faktiskās rīcības iedalïjums darbībā vai bezdarbībā, jo pārtraukt var tikai ilgstošu darbību. Ja faktiskā rīcība ir bezdarbības formā, tad tas, ka persona par to sūdzas tiesā, nozīmē, ka persona vēlas, lai iestāde veic kādu konkrētu darbību, uz kuru personai ir tiesības. Tāpēc pieteikuma priekšmets šādā gadījumā ir faktiskās rīcības veikšana, nevis bezdarbības

\footnotetext{
${ }^{13}$ Viškere I. 89. pants. Iestādes faktiskās rīcības jēdziens. Grām.: Administratīvā procesa likuma komentāri. A un B daḷa. Briede J. (zin. red.). Rīga: Tiesu namu aǵentūra, 2013, 896. lpp.

14 Turpat, 893. lpp.
} 
pārtraukšana. Piemēram, ja iestāde nav sniegusi personai pieprasīto informāciju, tad persona vēlas, lai iestāde veiktu faktisko rīcību - sniegtu informāciju.

Juridiski nozīmīgs ir arī apstāklis, vai faktiskās rīcības radītās faktiskās sekas ir tādas, kuras var pavērst atpakaḷ. Ja tas ir iespējams, tad pabeigtas faktiskās rīcība gadījumā (faktiskā rīcība darbības formā) tiesai ir jālemj ne tikai par šìs faktiskās rīcības atzīšanu par prettiesisku, bet arī par faktiskās rīcības seku novēršanu. Šādu situāciju Augstākā tiesa konstatēja lietā, kur ieslodzītais bija vērsies tiesā par faktisko rīcību, kas izpaudās kā sienas kalendāra izņemšana no sūtījuma, ko šim ieslodzìtajam bija sūtījis draugs. ${ }^{15} \mathrm{Lìdz}$ ar to faktisko rīcību ir iespējams iedalīt arī tādā, kuras radītās faktiskās sekas ir iespējams pavērst atpakaḷ, un tādā, kuras radītās faktiskās sekas nav iespējams pavērst atpakaḷ.

\section{Kopsavilkums}

1. Faktiskās rīcības daudzveidības raksturošanas nolūkā faktisko rīcību, balstoties uz tās pazīmēm, var klasificēt, piemēram, šādi: 1) darbība vai bezdarbība; 2) attiecībā uz amatpersonu vai iestādei īpaši pakḷautu personu veikta faktiskās rīcỉba un faktiskā rīcība, kas veikta attiecībā uz personu, kas nav amatpersona un nav iestādei īpaši pakḷauta persona; 3) rīcība, uz kuru privātpersonai ir tiesības, un rīcība, kuras rezultātā ir radies vai var rasties personas subjektīvo tiesību vai tiesisko interešu aizskārums.

2. Uz faktisko rīcību var attiecināt tikai dal̦u no administratīvā akta klasificēšanai izmantotajiem klasificēšanas veidiem.

3. Faktisko rīcību juridiski nozīmīgi ir iedalīt šādos veidos: 1) obligāta, brīva un daḷēji brīva faktiskā rīcība; 2) plānota un neplānota faktiskā rīcība; 3) vienreizēja un ilgstoša faktiskā rīcība; 4) darbība un bezdarbība; 5) faktiskā rīcība, kuras radītās faktiskās sekas ir iespējams pavērst atpakaḷ, un faktiskā rīcība, kuras radītās faktiskās sekas nav iespējams pavērst atpakaḷ.

15 Augstākās tiesas 09.03.2018. sprieduma lietā Nr. SKA-291/2018 (A420193115) 9.-12. punkts. Pieejams: http://www.at.gov.lv/lv/tiesu-prakse/judikaturas-nolemumu-arhivs/administrativo-lietu-departaments/ hronologiska-seciba. 